\title{
Analysis of genes coding for the sialic acid-binding adhesin and two other minor fimbrial subunits of the S-fimbrial adhesin determinant of Escherichia coli
}

\author{
T. Schmoll, ${ }^{4}$ H. Hosch Otzky, ${ }^{2}$ J. Morsehhäluser, \\ F. Lottepelch, ${ }^{3}$ K. Jann ${ }^{2}$ and J. Hacker ${ }^{1 *}$ \\ 'Institut für Genetik und Mikrobiologie, Röntgenring 11, \\ D-8700 Wirzburg, FRG. \\ ${ }^{2}$ Max-Planck-Institut für Immunbiologie, Stüboweg 51 , \\ D-7800 Froiburg, FRG. \\ 'Mex-Planok-Instilut fur Biochemie, D-8033 Martinsried, \\ München, FRG.
}

\section{Summary}

The S fimbrial adhesin (Sfa) enables Escherichis collt to attach to slallc ecld-containing receptor molecules of eukaryotic cells. As previously reported, the genetic determinant coding for the Sfa of an E. coll 08 strain wes cloned, the gene coding for the major fimbrial subunit was Identifled and sequenced and the $s$ specilic adhesin was detected. Here we present ovidence that in addition to the major subunit protein StaA three other minor subunit protelns, SfaG (17 kD), SfaS (14kD) and SfaH (31 kD) can be isolated from the 8-apecifie fimbrial adhesin complex. The genes coding for these minor subunits were Identified, mutagenized separately and sequenced. Uaing haemagglutination tests, electron-microscopy and quantitative ELISA assays with monoclonal anth-SfaA and anti-Sfas antibodles the functions of the minor subunits were determined. It was determined that Sfas is identical to the S-specific adhesin, which also plays a role in determination of the degree of fimbriation of the cell. The minor subunit SfaH also had some Influence on the lovel of fimbrlation of the cell, while SfaG is necessary for full expression of S-specific binding. It was further shown that the amino-terminal protein sequence of the lsolated StaS proteln was identical to the protein sequence calculated from the DNA sequence of the sfas gene locus.

\section{Introduction}

Adhesins represent structures of the cell envelope of bacteria which mediate attachment to organic and inorganic surfaces (Savage and Fletcher, 1985). They may play a role in the interaction of seprophytic and symblotic

Fecelved 28 June, 1989; revised 28 August, 1989. "For comeepondence. Tel. (831) 31378; Fax (831) 15123. bacteria with plant cell surfaces (Dazzo ot al., 1986; Korhonen ot al., 1988). Bacterial adhesins also enable pathogenic isolates of Gram-positive and Gram-negative specles to attach to receptor molecules of animal or human cells (Mirelman, 1986; Ott ot al, 1986; Meyer, 1987; Jann and Jann, 1989). Pathogenic bacteria may produce adhesins which are very often associated with fimbrial structures and are able to attach to enythrocytee. A single fimbria forms an appendage of the bacterial cell wall that is up to $2 \mathrm{~km}$ in length and is $2.8-7 \mathrm{~nm}$ in diameter (Klemm, 1985).

Escherichia coll isolated from extraintestinal sources may cause urinary-tract infections (UT), newbom meningitis (NBM) and sepsis (Orskov and Orskov, 1985). Fimbrial adhesins produced by extraintestinal $E$. coll can be distinguished by their receptor specilicity. Common type 1 fimbrial adhesins recognize $\alpha$-mannose in glycoproteins (Orskov and Orskov, 1983), and P fimbriae of uropathogenic $E$. coll interact with glycollpids containing $\alpha$-gal- $(1-4)-\beta-$ gal (Kallenius ot al, 1980). S-fimbrial adhesins expressed by $E$. coli causing UT or NBM attach to glycoproteins terminating with $\alpha$-siallic acid- $(2-3)-\beta$-gal (Korhonen of al., 1984; 1985; Parkkinen of al., 1986). For F1C fimbriae, which are genetically related to $S$ fimbriae, the receptor specificity has not yet been determined (ven Die ot al., 1985; Virkola ot al., 1988).

Genetic and biochemical studies of type 1 and $P$ fimbrlae have shown that the major fimbrillin proteins which form the fimbrial structure of the cells and the adhesin proteins represent two different molecules encoded by different genes of the fimbrial adhesin determinants (Lindberg ot al, 1984; Maurer and Ondortf, 1987; Minion of al., 1986). It was also shown that genes located at the immediate distal regions of the determinants code for the adhesins. In both cases the adhesins are proteins of about $30-35$ kiloDaltons (KD) (Klemm and Christiansen, 1987; Lund ot al, 1988a,b; Hanson and Brinton, 1988; Hoschützky et al, 1989). Recently the genetic determinant coding for the S-fimbrial achesin (Sfa) of an E. coll 06 strain was cloned and the DNA sequence of the major subunit gene was established. It was also demonstrated that the subunit gene is not identical to the adhesin coding locus (Hacker at al., 1985; Schmoll ot al., 1987; Ott et al, 1887). The adhesin of the S-epecific fimbrial adhesin complex (FAC) was isolated and monoclonal antlbodies specific for this proteln of $12-14 \mathrm{kD}$ 
(depending on the gel system used) were selected (Moch ot al, 1987 .

In this paper we show that the sfa determinant codes for the major subunit SfaA and three minor fimbrial subunit proteins, one of which is identical to the $\mathrm{S}$ achesin. It is further demonstrated that the achesin-speclic gene locus sfasis located at the distal region but not at the immediate 3 end of the determinant. The DNA sequences of sfaS and the other two minor subunit-specillc genes are determined, the N-terminal amino acid sequence of StaS is establiahed, and the functions of the corresponding proteins are analysed.

\section{Rosults}

\section{Dotection of minor subunits in the S-fimbrial adhesin complex}

The fimbria adhesin complex (FAC) of $\mathrm{S}$ fimbriae was isolated from recombinant clones harbouring the sfaspecilic plasmid, PANNB01-13, and the subunits were separated by heating the FAC in the presence of Zwittergent 3-16. As already shown previously, one protein of $16 \mathrm{kD}$, which represents the major fimbrial subunit of the S-fimbria adhesin complex (see Schmoll et d., 1987), was detected. Another three minor fimbrial subunits with molecular welghts of $14 \mathrm{kD}, 17 \mathrm{kD}$ and $31 \mathrm{kD}$ were aiso found after separation using SDS-PAGE (see Fig. 1, lane G.

\section{DNA sequence of the genes coding for the minor fimbrial subunits of Sfa}

It was shown that the genes coding for the minor fimbrial subunits must be located at the distal part of the sfa

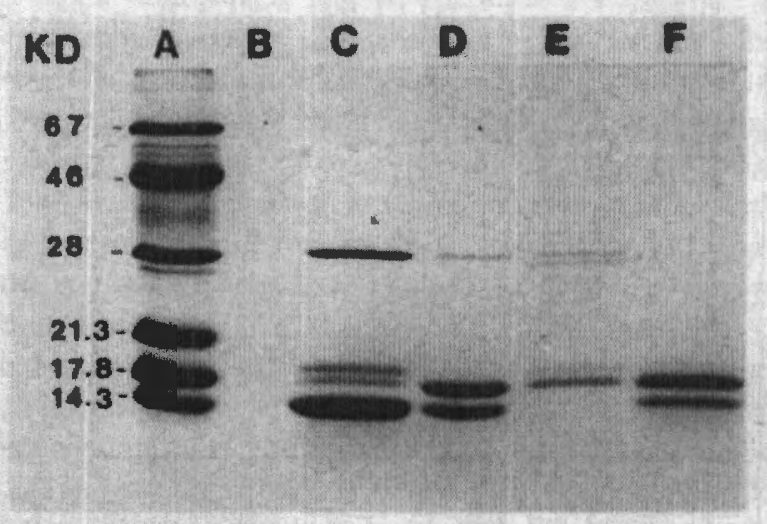

F. 1. SDS-PACE anabris of moior and minor subunit proteins of the S-fimbrial adhesin complexes encodod by she wild-type and mutant gane clusters. The tollowing clones are indleated: HB101(pBR322), tane B: HB101(pANN801-19, of t), lene C; HB101(oNN801-1320, sho -) lane D; HB101(pANNe01-1321, ans"), lane E; HB101(pANN801-13Ths. OSS, stah 7. lane F. Line A: size markers. determinant (Hacker ot al., 1985; Moch et al., 1987). In order to characterize these genes more accurately we have sequenced the corresponding region of 2.3 kilobases (kb) of DNA (Flg. 2). As indicated in Fig. 2, three open reading frames (ORFs) were found. One ORF starts at an ATG codon at position 61 to 63 and the gene ends at a TAA at position 586 to 588 . The second ORF extends from position 610 to 1101 and the third gene is located between positions 1163 and 2038 . The three open reading frames represent three genes which have been designated sta $C$. sfas and sfaH. The three genes code for three mature proteins with calculated molecular masses of $14.9 \mathrm{kD}$, $16.8 \mathrm{kD}$ and $29.1 \mathrm{kD}$. The molecular weights of the three putative proteins calculated from the DNA sequences are similar to those of the minor subunils isolated from the fimbria adhesin complex (see Fig. 1).

\section{Mutations in the genes sfaC, sfaS and sfaH}

The recombinant DNAs pANNBO1-1320 and pANNBO11321 were constructed to carry frameahift mutations in the genes sfaG and sfas (see the Experimental procedures and Fig. 2). In addition, three Ths mutants of the staspeciflc recombinant plasmid PANN801-13 were analysed. It was shown by DNA sequence studies that the Tn5 mutants pANN801-13/Tn5-033 and PANN801-13/ Tn5-026 camy the transposon inserted in the gene sfaH at positions 1248 and 1543, respectively (see Fig. 2). In Mutant pANN801-13/Tn5-020, a Tn5 transposon was inserted into the gene sias at map position 622. Because transposon Th5 causes polar effects (Berg and Berg. 1983), sfaH was eliminated together with sfas in the latter mutant.

From the HB101(pANN801-1320), HB101(pANN8011321) and HB101(pANN801-13/Tn5-033) mutant clones the major and minor subunit proteins were lsolated and separated using SDS-PAGE. As demonstrated in Fig. 1 (lanes D-F), the sfaG-negative mutant, HB101(pANN8011320) had lost the $17 \mathrm{kD}$ subunit protein whereas the sfaS-negative clone HB101 (pANN801-1321) did not produce the $14 \mathrm{kD}$ minor component. In the staH-negattve strain, HB101(PANN801-13/Tn5-038), the 31kD protein was eliminated. In all mutant clones tested, the major subunit protein of $16 \mathrm{kD}$ was still present. These results clearly demonstrate that the genes sfaG, sfas, and sfaH code for minor fimbrial subunit protelns of $17 \mathrm{kD}$ (StaG), $14 \mathrm{KD}$ (SfaS) and $31 \mathrm{kD}$ (SfaH) in aize.

\section{Further characterization of clones camying mutations in the gones stac, sfaS and sfaH}

In order to analyse the functions of the minor subunit proteins of the S-fimbrial adhesin complex the mutant clones mentioned above, the wild-type sfa determinant 

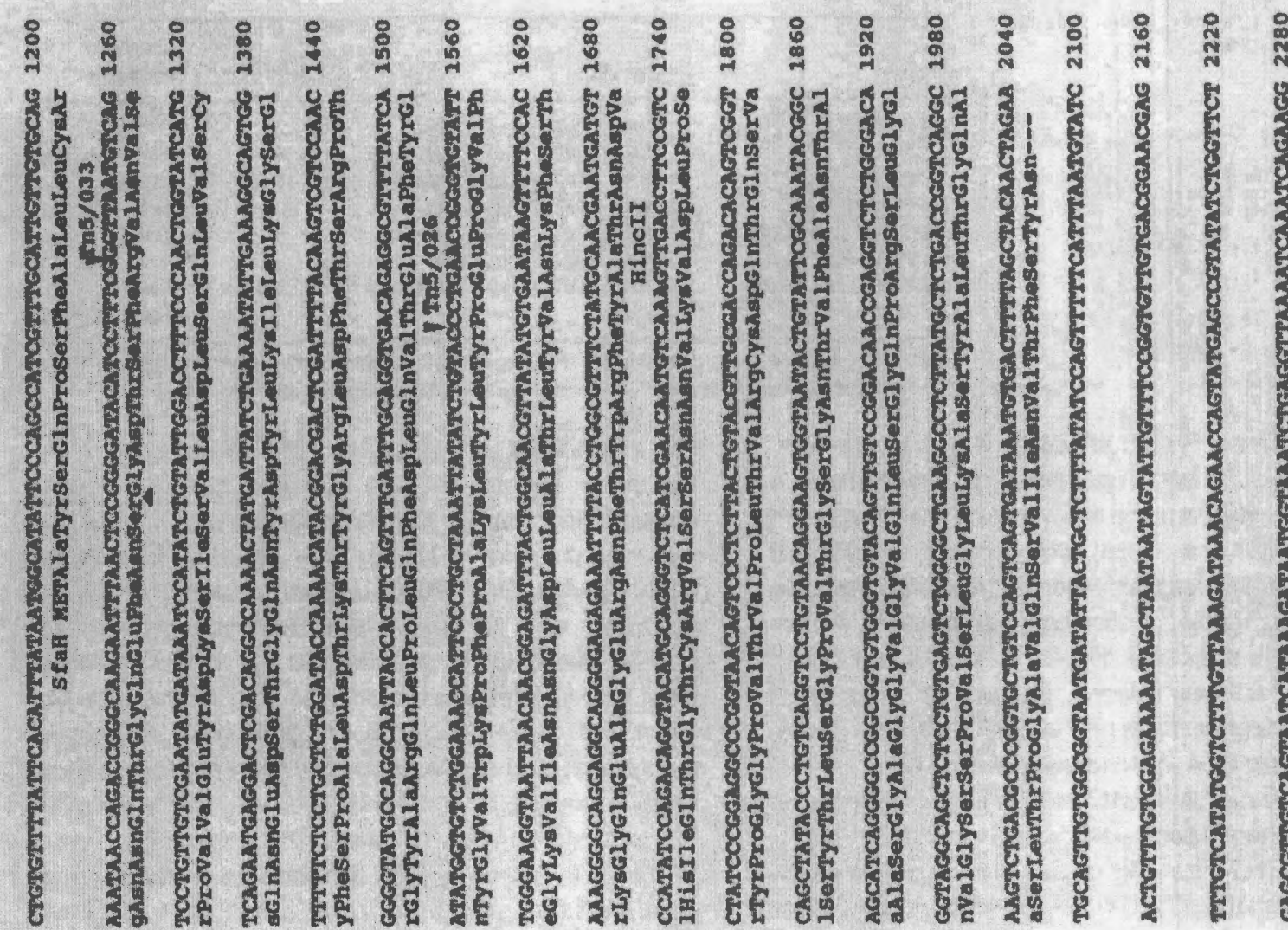

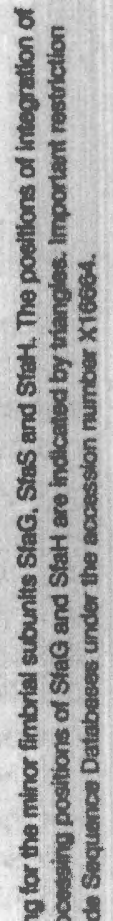

:

.5

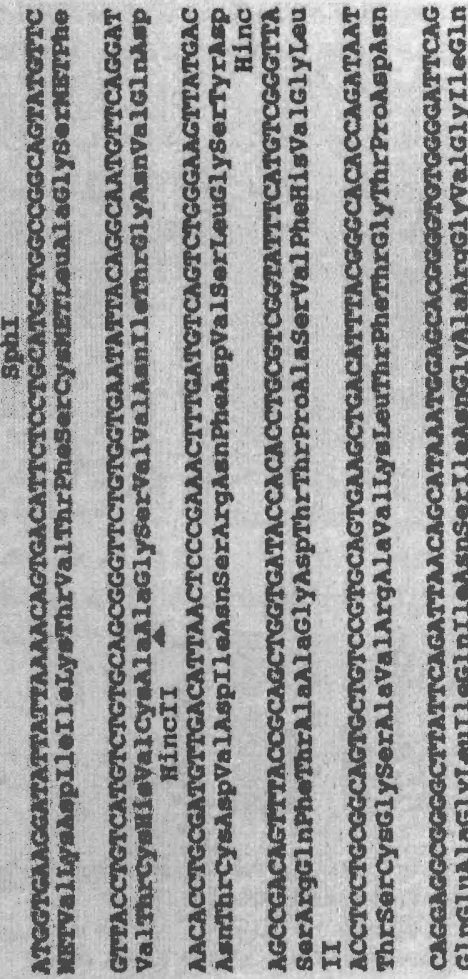

类带

हुำ

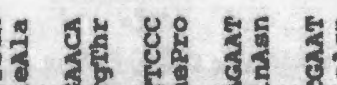

త్

를 \&

8

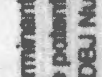

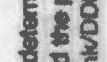

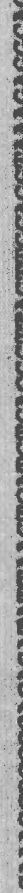

I

है है

คํํㅇ

क्ष०त

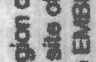

$\frac{8}{8}$

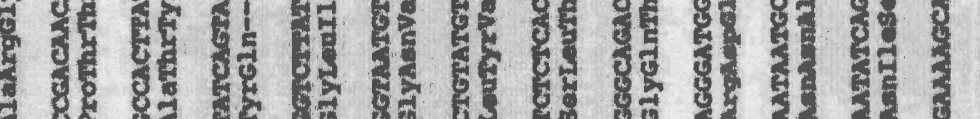

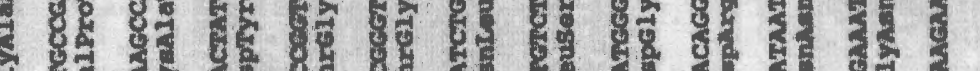

के

8.

学

क्षे

항

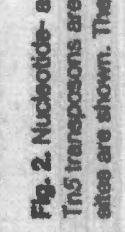


Teble 1. Characterization of E coll K12 clonves canying sta-tipedilo DNAs.

\begin{tabular}{|c|c|c|c|}
\hline Plawnid & Cenotype & HA-these & $\begin{array}{l}\text { Degree of } \\
\text { fimbritition }\end{array}$ \\
\hline PANME01-13 & $\operatorname{sha}^{+}, \operatorname{sho}^{+}, \operatorname{shs}^{+}, \mathrm{ahH}^{+}$ & 32 & Heany \\
\hline PAWNEO1-1 & $\operatorname{staA}^{-}, \mathrm{staO}^{+}, \mathrm{sfaS}^{+}, \mathrm{otaH}^{+}$ & 8 & Non-fimbitated \\
\hline DNNNE0t-1320 & $\operatorname{staA}^{*}, \sin ^{-}, \mathrm{oth}^{+}, \mathrm{staH}^{+}$ & 16 & Hoevy \\
\hline PANNE01-1321 & 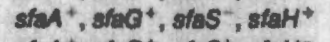 & 0 & Low \\
\hline PANNE01-18/Tn5-038 & $\operatorname{staA}^{+}, \operatorname{sta}^{+}$, sth $^{+}$, sher & 8 & Low \\
\hline PANNE01-13/Th5-028 & $\operatorname{staA}^{+}$, athet, stast, ather & 8 & Low \\
\hline PANME01-13/mn5-020 & $\operatorname{stan}^{*}, \operatorname{sta}^{*}, \operatorname{sfas}^{-}, \operatorname{staH}^{-}$ & 0 & Low \\
\hline pBAse2 & Control & 0 & Non-innbrated \\
\hline
\end{tabular}

2. Haemagglutihation was carried out in microtitre plates as described by Jones end Rutter (1972).

b. The degree of fimbriation was evaluated ueing electron micrescocy (bee albo Fla. A).

encoded by clone HB101(PANN801-13) and the nonfimbrlated subclone HB101(PANNB01-1), which shows a deletion of the major fimbrial subunit gene sfaA (Hacker ot al. 1985; Schmoll et al., 1987), were further characterized in a quanttative haemagglutination test and in quantitative ELISA assays using monocional antibodies (Mabs) directed agalnst the major fimbrial subunit (MabF1) and the S-specilic adhesin (MabA1) (Table 1 and Fig. 3). In addition, the degree of fimbriation of these clones was ovaluated by electron microscopy (see Fig. 4).

As demonstrated in Table 1 and Fig. 4, only mutants with the mutagenized gene sfas (DANN801-1321; PANN801-13/Tn5-020) were unable to recognize enythrocytes in a haemagglutination assay, although they were still fimbriated. In addition, the stas-negative clones also falled to react with the anti-adhesin monocional antibodies (see $\mathrm{Flg}$. 3), It was also demonstrated that the sfas-negative mutants showed reduced values in the quantitative ELISA with the fimbrial-speclific MabF1. In addition, the degres of fimbriation of these clones was decreased in comparison with the sfa wild-type clone

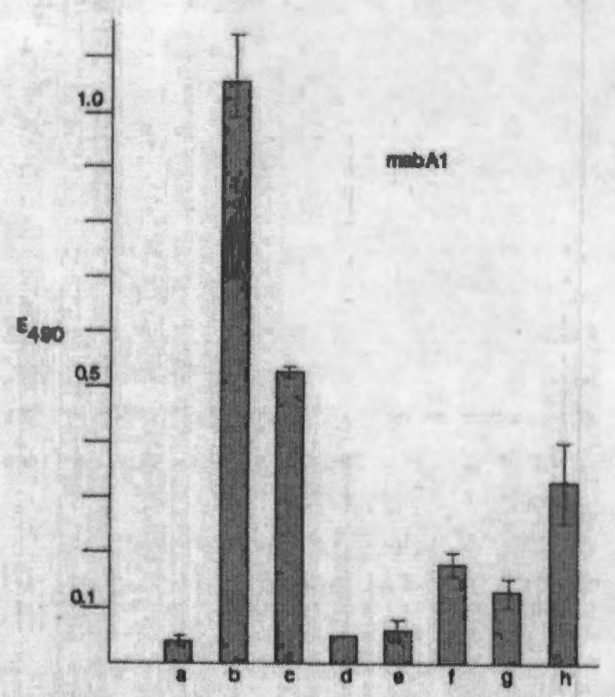

HB101 (pANN801-13) (Figs 3 and 4). These data show that the minor subunit SfaS is identical to the S-8pecilic adheain. In contrast to the sfaS-negative clones, the sfatH-negative clones HB101(pANN801-13/Tn5-033) and HB101(pANN-13/Tn5-026) showed heemagglutination and were able to bind the anti-adheain-specific antlbodies. The binding capacities of the strains, however, were strongly reduced relative to that of the wild-type clone HB101(PANN801-13). As indicated by electron microscopy and ELISA tests with the anti-StaA entlbody MabF1, the degree of fimbriation was also decreased in the two sfaftnegattve clones. The clone HB101(DANN801-1320), which carries a frameshift mutation in the gene sfa $G$ also gave a low value in the ELISA assay with the anti-adhesin MabA1 and gave a decreased haemegglutination titre relative to that of the sfa wild-type gene cluster (Fig. 3, Table 1). The level of fimbriation and the ELISA value with the fimbrial-specific antibody (MabF1) of this clone, however, were comparable to what has been found for the wild-type gene cluster located on plasmid PANN801-13 (Figs 3 and 4).

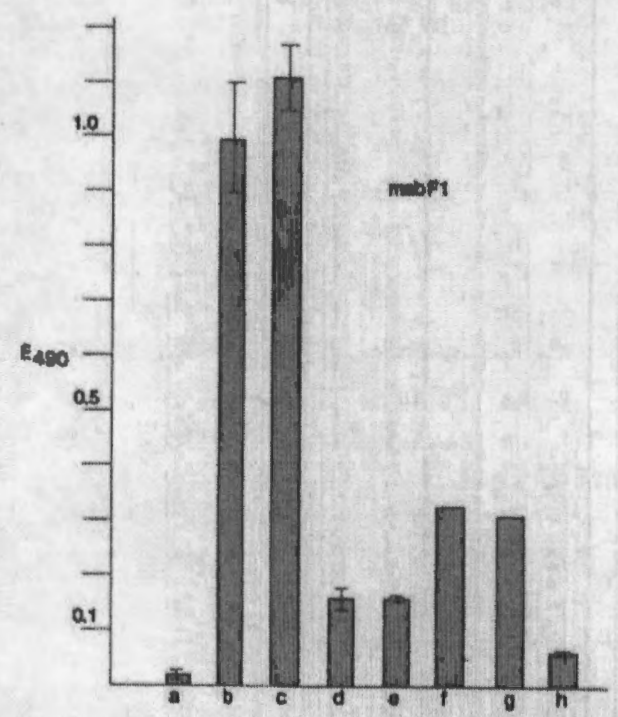

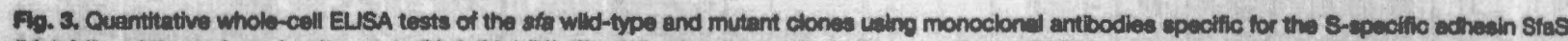

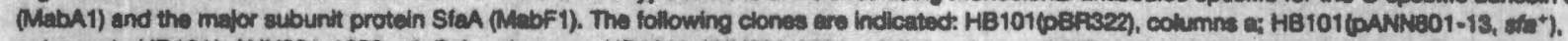

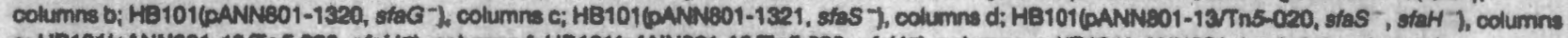

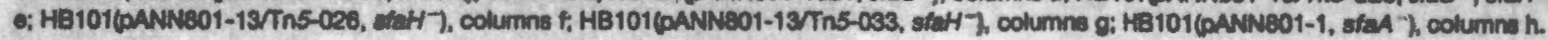




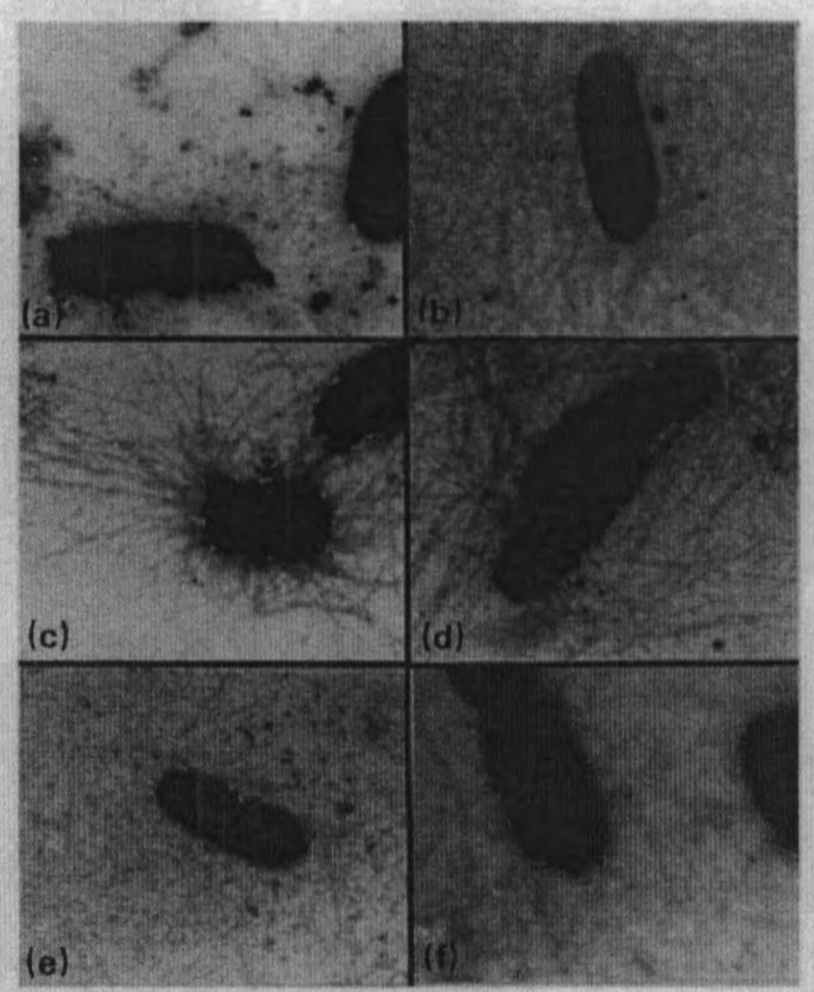

Fr. 4. Electron microcraphs of the sta witht type and mutant clones. The following strains are indicated: a, HB101(0BP322); b, HB101(DANiNa0113, sat)i c. HB101(DANNBO1-1320, sac ); d, MB101(DANNE01-1321,

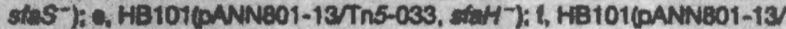
Tns 020, atas., Ha $^{-1}$ ).

Protein sequence enalysis of the N-terminal part of SfaS and the priney sequence of the three minor Sfa subunit proteins

The $N$-terminal sequence of the mature protein SfaS, which is able to bind to human and bovine erythrocytes after purification (see Moch ot al., 1987), was determined. It was shown that the first amino acid residues of the mature protein were valine, espartic acld and threonine (see Figs 2 and 5. Therefore it is clear that the first 22-amino-acid residues of the precursor protein were cleaved following transport. All the 40 -amino-acld residues of the $\mathbf{N}$ terminus of the mature Stas protein determined were identical to those of the protein sequence deduced from the DNA sequence of stas, as indicated in Fig. 2.

It is evident from Figs 2 and 5 that the three proteins StaG, StaS and SfaH carry tyrosine residues in the second last position of the sequences. In addition, two (or, in the case of the $31 \mathrm{kD}$ protein SfaH, four) Cysteine residues are located at well-defined positions which may form Cys-Cys bridges in native proteins (Jann ot al., 1981). The presence of the tyrosine residues in the $C$ termini and the cysteine residues are characteristic of the primary sequences of fimbrial subunit proteins (Hacker, 1989).

\section{Diacuselon}

In this paper we demonstrate that the fimbrial achesin complexes of $E$. coll S-fimbrial adhesins consist of four components: the major subunit SfaA, a protein of $16 \mathrm{kD}$ and three minor fimbrillins designated SfaG, SfaS and StaH (proteins of $17 \mathrm{kD}, 14 \mathrm{kD}$ and $31 \mathrm{kD}$, respectively). It is also shown that mutations in sfaS, but not in sfaG, sfaH or siaA, completely eliminated S-specific binding, indicatIng that SfaS represents the S-specific adhesin (see Table 1). In addition, StaS and also SfaH-negative clones showed a significant reduction in fimbriation of the cells (Figs 3 and 4). It is therefore concluded that SfaS and StaH also play a role in the determination of S-specific fimbriation. A mutation in sfaG did not influence fimbriation of the cells but reduced the binding capacity of the clones. It is suggested that SfaG acts as a linker molecule for the adhesin which could bind the SfaS protein to the fimbriaa.

The minor subunits of P fimbriae of serotypes F13 (oap). $F_{1}$ (fso), $F_{2}$ (tst) and of type 1 fimbriae (fim), which are Indicated in Fig. 6, represent proteins of molecular welghts equivalent to those of SlaG, SiaS and SfaH. These minor fimbrillins also play a role in the determination of the degree of fimbriation of the cells and in anchoring the adhesins to the fibre-like structures. The F protein of the fst gene cluster (equivalent to SfaS) and the G proteins of tso, fst and pap determinants (equivalent to StaH) are necessary for heavy fimbriation of cells (Undberg et al., 1987; Riegman et al., 1988). In the case of type 1 fimbriae, the proteins FimF and FimG, which are equivalent to StaG and SfaH, are Involved in modulation of fimbriation (Klemm and Christiansen, 1987; Krogielt and Klemm, 1988).

It is also shown in Fig. 6 that the genes coding for the minor subunits of $\mathrm{P}$ fimbriae of different serotypes, of type 1 fimbriae and of $S$ fimbriae are located at the $3^{\prime}$ ends of the determinants. The minor subunits PapG and FinH, proteins of $35 \mathrm{kD}$ and $32 \mathrm{KD}$, respectively and equivalent to the SfaH protein represent the P (F13) and type 1-specific adhesins (Lindberg ot al., 1987; Lund of al, 1987; Hoschutzky of af., 1989; Klemm and Christiansen, 1987; Hanson end Brinton, 1988). Adhesins of similar molecular weights are also encoded by P-fimbrial gene clusters of other serotypes (Lund ot al., 1988a,b; Riegman ot al., 1988). While the largest protein of the minor P-and type 1 subunits represents the adhesin of these attachment factors, the S-specific adhesin is identical to the smallest subunit of the S-fimbrial adhesin complex. The gene sfas is located at equivalent positions to the $F$ gene loci of P-specific determinants and to the gene fimG of the type 1 gene cluster (Flg. 6). Thus in contrast to $P$ and type 1 determinants, the S-specific adhesin locus is not located at the immediate distal part of the sfa gene cluster. Summarizing these data, it seems that a 'functional shift' 
$1740 T$ T. Schmoll et al.

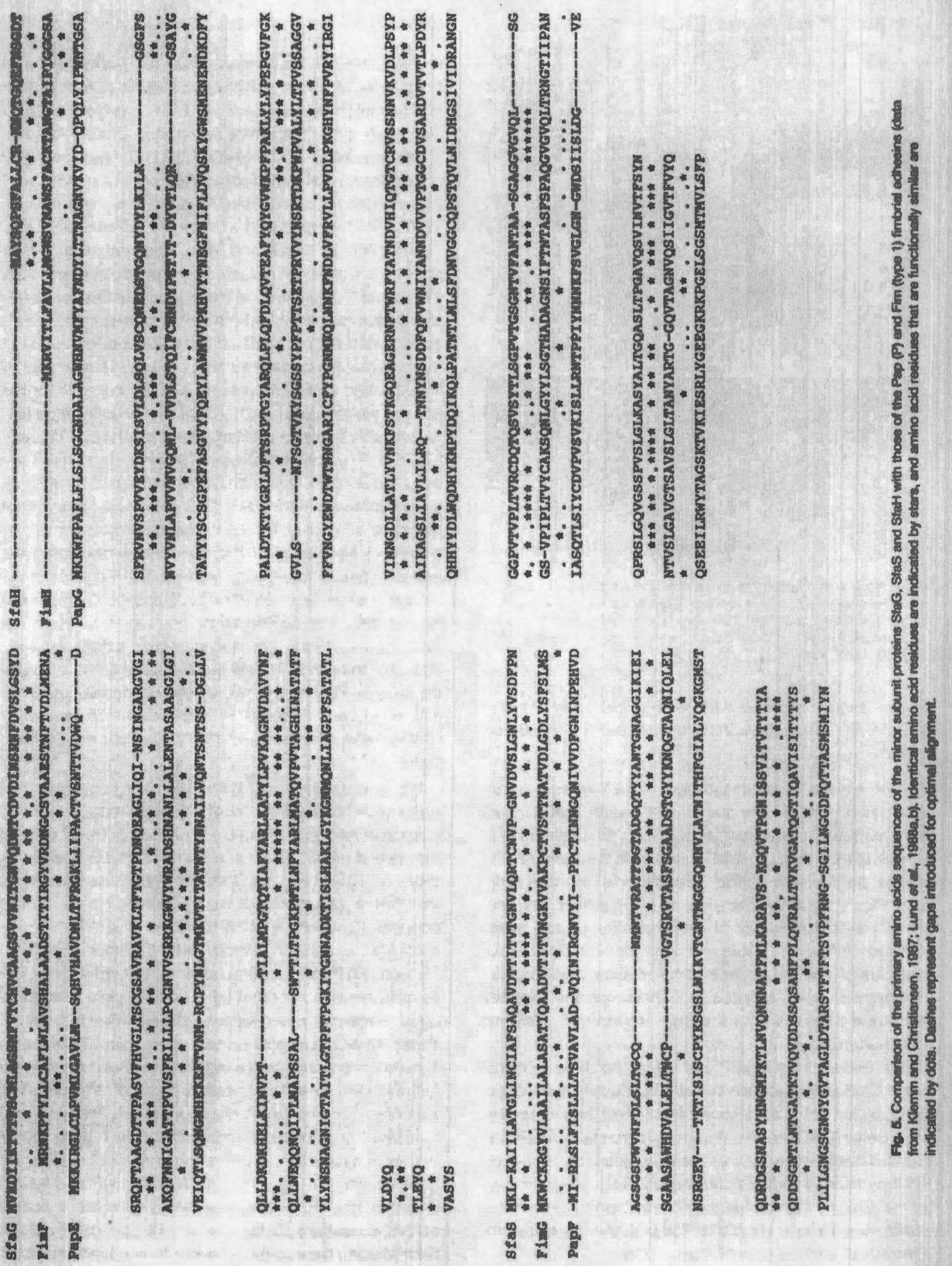




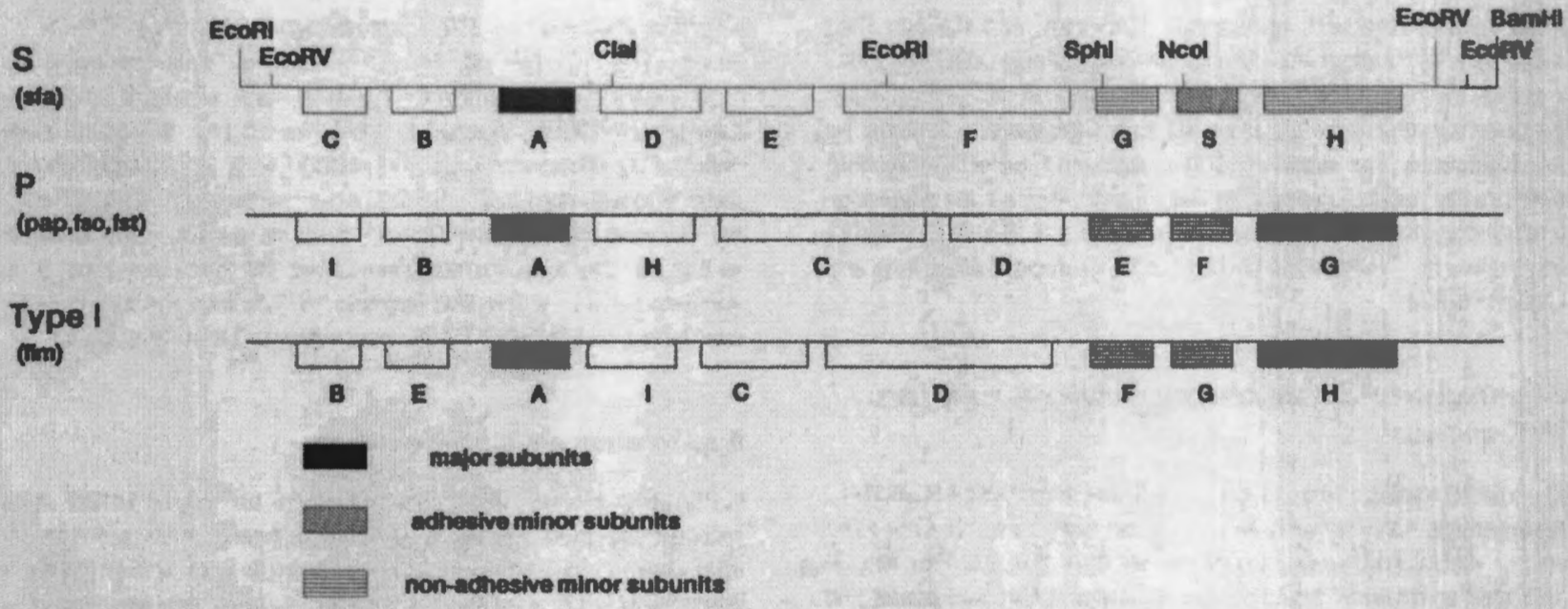

Fla. 6. Comparlsen of the centic organization of the S-epecific ste determinant (Hacker, 1989) and the cene clusters coding for R. end type 1-thibries. The gene locl are indicated by boxes. The luttors bolaw the P-specilic determinant merk the genes of pap, fat and fso determinants (Lund of al, 19a8ab; Rlegman et el., 1889). The lotturs below the type 1 -epectile determinent mark the genes of the fin daterminent (Kemm and Chribtiansen. $1987 ; H$. Bergmans and H. Klemm, personal comminication). The boxes spectic for major and mincr subunit genes are indlcated by specilic patterns. The open boxes represent genes isvolved in regulation (the boxes of the left site) and in traneport and assembly procesese. The main directions of tranecription ane from len to right. Important restriction eltes of the sfa determinant are indicated.

had occurred among the minor subunit genes of $P$ and type 1 fimbriae on one hand and S-fimbrial achesins on the other hand because different minor subunlits represent the corresponding adhesins.

The functional differences established among the minor subunits of P, S and type 1 fimbrial achesins are also reflected in the primary proteln sequences (see Flg. 5). After comparison of the amino acid sequences of the equivalent subunits it is evident that the achesin SfaS shows a smaller degree of homology to the corresponding proteins FimG (44.3\%) and PapF (32.6\%) compared with SfaG and StaH, which are more homologous to their P. and type 1-specific counterparts. In general, the relatedness among the minor subunits is more pronounced between the sta- and the fin-encoded proteins compared with sta- and pap-specific fimbrillins. These results are in line with sequence data for the major subunit proteins. The major subunit proteins SfaA and FimA are more related to each other than SfaA and PapA fimbrillins (Schmoll et al., 1987). From an evolutionary point of view, it can be speculated that the genes specifle for major and minor fimbrial subunits of $S$ and type 1 fimbriae may have been evolved from a common ancestral gene cluster. It is interesting to note that the $\mathrm{N}$ and $\mathrm{C}$-terminal portions of the proteins show the highest degree of relatedness (see Fig. 5). These regions may play a role in the interaction of subunits during fimbria formation (Klemm, 1985) and are therefore more conserved among the different subunit proteins than the other regions of the different fimbrillin protelns.

\section{Exporimentel procedures}

\section{Media, enzymes and chemicals}

Bacteria were grown in enriched nutrient broth or in L-broth. For Isolation of fimbrial subunits, the clones were grown in a medlum containing $1 \%$ bactopepton, $1 \%$ yeast extract, $0.25 \%$ olycerine and $50 \mathrm{mM}$ sodlum phosphate buffer $(\mathrm{pH} 7)$. Radlochemicals were purchased from New England Nuclear Comp. (Boston, MW. and antibiotics were a gift from Bayer (Leverkusen, FRC). All other chemicals were obtained from E. Merck AQ (Darmatad, FRC). Restriction enzymes and T4 ligase were purchased from Bio-Rad Laboratories (Richmond, CA). DNA polymerese I was obtained from Bochringer (Mannhelm, FRC).

\section{Bacterial strains and plasmids}

All recombinant plasmids were transformed into the $E_{\text {coll }} \mathrm{K} 12$ strain HB101. The different S-fimbrial adhesin (sta)-epecilic recombinant DNAs were dertved from the plasmid pANNE01-13

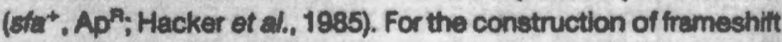
PANN801-12 and PANN801-11 were used. pANM801-12 (Tch) carries a $4.7 \mathrm{~kb}$ EcoRI fragment which represents the proximel part of the sfa determinant and PANNB01-11 (ApP) harbours a $5.3 \mathrm{~kb}$ BamHVEcoRI fragment specific for the distal pert of the sta gene cluster (Hacker of al., 1985; Ott et al., 1988; see also Flg. 6). The Tn5 insertion mutants pANN801-13/Th5-038, pANNB01-13/ Tn5-028 and PANN801-13/Tn5-020 have been described previously (Hacker et al., 1985).

\section{Rocambinant DNA techniques}

Plasmid DNA was isolated as described earler (Grinstedt ot al. 1978; Bimboim and Doly, 1979). For restriction enzyme analyals, 
DNA was treated with appropriate enzymes, and the reaulting fragments were separated by gel electrophoreais on 0.7 to $1.0 \%$ agarose gels as described before (Knapp of $1.1,1884$ ). DNA fragments were lsolated after agarose gel electrophoresls by electroalution. For cloning, DNA fragments were ligated into sultable vector molecules after heat-inactivation of the restriction endonucloases at $65 . \mathrm{C}$ for $6 \mathrm{~min}$ (Manlatis ef aL, 1982). E. collK12 stralns were transtormed by the $\mathrm{CaCl}_{2}$ method (Lederberg and Cohen, 1974).

\section{Construetion of clones carrying mutations in the genes sfac and stas}

In crder to mutagenize the gene staC, the plasmid pANNB01-11 was partlally cleaved with tha restrictlon enzyme Sphl. One Sphl site is located in sfoc at position 88 (cee Fig. 2). The singlostranded enda were digested with the help of T4 polymerase and the blunt ends were ligated. For mutagenlzation of staS, pANN801-11 was cleaved with the reatriction enzyme Ncol. A NCol atte is located in the gene slas at postion 799 (Flg. 2). The single-stranded ends were filled by a Klenow reaction. In order to control the reactions, DNA was isolated from 20 putative sfacnegative and 20 sfaS-negative mutants and cleaved wth Sphi and Ncol, respectively. Two recombinant plesmids (pANNBO113201 and PANN801-13211) with destroyed recognition sites were sequenced around the former Sphl and Ncol stites using the DNA plasmid sequencing ktt of Boehinger. The sequences gave clear-cut evidence that frameshift mutations had been introduced into the genes sfac and stas. In order to restore the sfa determinant, the $4.7 \mathrm{~kb}$ EcoPl fragment of pANNBO1-12, which represents the proximal part of the sfa determinant, was llgated into the ECORI site of plasmids pANNB01-13201 and pANNB0113211, respectively. The clones were screened using a DNA-DNA colony dot blot (Maniatis at al., 1982). It was shown by DNA cleavage that constructs pANN801-1320 and PANN801-1321 were identical to the wild-type plasmid pANN801-13, with the exception of the two frameahift mutations.

\section{Determination of the insertion points of the Th5 mutants}

In order to determine the exact position of Tns insertion into the pANN801-18 derivatives pANN801-13/Tn5-026, pNN801-13/ Tn5-020 and pANN801-13/Tn5-083, the DNAs were cleaved with the restriction enzyme Hoal and sultable DNA fragments cernytho 195 Tn 5 -epecilic bp together with some sta-specilic reglons were ligated into the vectors pUC18 and pUC19. The DNA sequences of the insertion points were determined by the plasmid sequence technique with the help of the DNA sequencing kft from Boehringer.

\section{Isolation of the fimbria achesin complex and separation of major and minor subunits}

Tha leolation of the fimbria achesin complexes and the separation of the eubunits were carried out as described recently by Moch of al. (199n) and Hoschutzky ot al. (1989) with the following modilcations: agar-grown bacterla were suspended in phosphate-buffered sellne (PBS) and agitated twice for $5 \mathrm{~min}$ with an omnimixer. Bacteria were removed by centrifugation $(20000 \times \mathrm{g}$, $40 \mathrm{~min}$ ) and the fimbriae were concentrated by ammonium sulphate precipltation (20\% saturetion) followed by dialyels to $10 \mathrm{mM}$ Tria-HCl $(\mathrm{pH} 8)$. Insoluble material was removed by centritugation. The fimbriee solution was adfusted to $0.5 \%$ Zwittergent-16 and heated to $50^{\circ} \mathrm{C}$ for $30 \mathrm{~min}$. Fimbrias were pelleted by ultracentrifugation $(140000 \times 9,2 h)$, suepended in water and adjuated to $0.5 \% \mathrm{SDS}$. Alter heating to $70^{\circ} \mathrm{C}$ for $30 \mathrm{~min}$, the fimbriae were pelleted by ammonlum sulphate precipitation as before. The supernatant (containing the minor subunits) was dlalysed agalnat water and lyophlilzed. The minor subunits were analyeed by $15 \%$ SDS-PAGE according to Laemmll (1979).

\section{Agglutination and adhesion tests}

Fimbriated clones were characterized by agglutination with anticera on glass slides, S-spectilic adhesion was determined after mixing the bacterlal calls with human and bovine enythrocytes with and without $2 \%$ mannose and with erythrocytes treated with neuraminidase (Korhonen et al., 1984; Hacker et al., 1985). In order to quentttate the haemegalutination property the test was done in microtite plates ss described by Jones and Rutter (1972). The haemaggiutination (H4) tests were carried out at pH 7.

\section{Electron miloroscopy}

For electron microscopy, the bacterla were transferred to copper grids coated with polyvinyl-Formvar. After eoeking in $1 \%$ phosphotungstio acid $(\mathrm{pH} 6.4$ ) for $1 \mathrm{~min}$, the grids were examined under a Zelss $10 \mathrm{~A}$ transmission electron microscope.

\section{Preparation of monocional antisera}

The preparation and characterization of the monocional antibera used heve been described proviously (Moch ot d., 1987).

\section{ELISA}

The quentitative enzyme-linked immunosorbent assay (EUSA) was performed with whole bacteria according to the method of Boylan ot al. (1887).

\section{Oligonucleotide synthesls}

Ollgonucleotides were synthesized in an Applled Blosystems 380 A DNA synthesker using the phosphoramidlte method of Beaucage and Caruthers (1981). Ollgonucleotides were purified on a polyacryiamide gel.

\section{DNA sequencing}

The sequences of the DNA region coding tor the genes sfaG, stes and staH were determined by the sanger technique with the M13mp18/mp19 system described previously (Hu and Messing. 1982). Sequences of the Tns insertion and the frameshift mutants of plasmid PANNBO1-13 were determined with the help of a sequence kit from Bochringer, according to a protocol supplled by the manufacturer. 


\section{Protein sequencing}

The proteln was subjected to $12 \%$ SDS-PAGE and electroblotted onto a sillconized glassfibre sheet (glassy bond. Blometra) essentially as described by Eckerakom et al. (1988). The Siascontaining band was excised and sequenced in an Applied Blosystems 477A gas-phase sequencer.

\section{Computer analysis}

The programs used for compiling the nucleotide sequence data were from J: Dovereux (UWGCG).

\section{Acknowledgements}

We thank Balakrishna Pillay (Worzburg) and Mike Wuenscher Wurzburgl for critical reading of the manuscript, and Wilma Schmitt (Wirzburg) for editorial assistance. The work was supported by the Deutsche Forschungegemeinschaft ( $\mathrm{Ha} \mathrm{1434}$ ) 1-6) and the Fond der Chemischen Industrie.

\section{Foferences}

Beaucage, 8.L, and Caruthers, M.H. (1981) Desoxynucleoside phosphoramidites: a new class of koy intermediates for desoxynucleotide synthesle. Totrahodron Lott 22: 1859-1862.

Berg, D.E, and Berg, C.M. (1983) the proceryotic transposable element Th5. Blotechnology 7: 417-435.

Bimboim, H.C., and Doly, J. (1979) A rapld alkaline extraction procedure for screening recombinant plasmid ONA. Nucl Acids Res 7: 1513-1522.

Boylan, M., Coleman, D.C., and Smyth, C.J. (1887) Molecular cloning and characterration of the genetic determinant encoding CS3 fimbriae of enterotoxigenic Escherichila coll. Microb Pathogen 2: 185-209.

Dazzo, F.B., KIJne, J.W., Heahtela, K, and Korhonen, T.K. (1986) Fimbriae, loctins and agglutinins of nitrogen fixing bacterta. In Microbial Lectins and Agglutinins: Propertios and Blological Activity. Mirelman, D. (ed.). New York: Wiley Interscience Press, pp. 237-254.

van Die, L., van Megen, R., Hoekstra, W., and Bergmans, H. (1984) Molecular organizatlon of the genes involved in the production of $\mathrm{FT}_{2}$ fimbriae, causing mannose resistant hemagglutination of a uropathogenic Escherichia coll O8:K2:H1:F7 strain. Mol Gen Genet 194: 528-533.

van Die, $L_{\text {, }}$ van Gefien, R., Hoekstra, W., and Bergmans, H. (1985) Type tC fimbrias of a uropathogenic Escherichia coll strain: cloning and charecterization of the genes involved in the expression of the $1 \mathrm{C}$ antigen and nucleotide sequence of the subunit gene. Gene 34: 187-196.

Eckerskom, C., Mewes, W., Gorotzki, H., and Lottspelch, F. (1988) A new siliconized glass fibre as support to protein chemical analysis of electro-blotted protein. Eur $J$ Blochem 175: $509-519$.

Grinstedt, L, Bennett, P.M., Higginson, S., and Aichmond, M.H. (1978) Reglonal preference of insertion of Tn 501 and Tn 802 into RP1 and its derivathes. Mol Gen Genot 166: 313-320.

Hacker, J, Schmidt, G., Hughes, C., Knapp, S., Marget, M., and Goebel, W. (1985) Cloning and characterization of genes involved in production of mannose-resistant, neuraminidesesusceptiblo $D$ fimbriae from a uropathogenic O6:K16:H31
Escherichla coll strain. Infoct Immun 47: 434-440.

Hacker, J. (1989) Genetic determinants coding for fimbriae and adhesins of extraintestinal Eacherichie coll. Cur Top Microbiol Immund 181: 191-217.

Hanson, M.S., and Brinton, C.C. (1988) Identification and characterization of $E$. coll type I pllus tip adhesion protein. Nature 332: 285-268.

Hosch Otzky, H., Lottspoich, F., and Jann, K. (1989) Isolation and characterization of the alphe-Galactosy-1,4-beta-Calactooyspecific adhesin (P adhesin) from fimbriated Escherichla coll. iniect immun 57: 70-81.

Hu, N., and Messing, J. (1982) The making of atrand-epectic M13 probes. Gene 17: 271-277.

Jem, K, Jann, B., and Schmidt, G. (1981) SDS potyacrylamida gel electrophoresis and serological analysis of plli from Escherichla coll from different pethogenic origin. FEMS Microblol Lett 11: 21-25.

Jann, K, and Jann, B. (eds). (1989) Bacterisl capsules and adhesins - facts and principles. Cur Top Mlorobiol Immunol 151: in press.

Jones, G.W., and Rutter, J.M. (1972) The association of KB8 antigen with hemaggluthation activity in porcine strains of $E$. coli. J Cen Micrabiol 64: 136-144.

Kallonitu, E., Mölby, R., Svenson, S.B., Winberg. J., Lundblad,

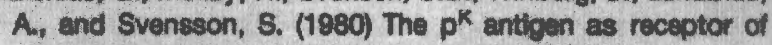
pyolonephritic E. coll. FEMS Microblol Lett 7: $297-300$.

Klemm, P. (1985) Fimbrial achesins. Rev int Dis 7: 321-340.

Klemm, P., and Chriatiansen, G. (1987) Three fim genes required for the regulation of length and mediation of achesion of Escherichla coll, type I fimbriae. Mol Gen Genet 208: $439-445$.

Knapp, S., Hacker, J., Then, I., Müller, D., and Goebel, W. (1894) Multiple coples of hemolyein genes and associated sequences in the chromosome of uropethogenic Escherichia coli straine. $J$ Bacteriol 159: 1027-1033.

Korhonen, T.K, Valsänen-Phen, V., Phen, M., Pere, A, Parkkinen, J., and Finne, J. (1984) Escherichia coll fimbriae recognizing sialyl galectosides. $J$ Becterlol 159: 702-763.

Korhonen, T.K, Vattonen, M.V., Parkdinen, J, Valsänen-Rben, V., Finne, J., Orskov, F, Orskov, I., Svenson, S.B., and Makeda, P.H. (1985) Serotype, hemolysin production and receptor recognition of Escherichla col/straina associated with neonatal sepsis and meningitls. Infoct Immun 48: 486-491.

Korhonen, T.K., Haahtela, K., Romantechuk, M., and Bamiord, D.H. (1988) Role of fimbriee and pill in the attachment of Klobsiolla, Enterobacter and Pseudomonas to plant surfaces. In Recognition in Microbe-plant Symblotic and Pathogenic Interactions. Vol. 4. Lugtenberg, B. (ed). NATO ASI Series H, pp. 229-242.

Krogfelt, KA, and Klemm, P. (1988) Investigation of minor components of Escherichia coll type I fimbrlas: proteln, chemlcal and Immunological aepecta. Micrab Pathogen 4t: 231-238.

Laemml, U.K. (1979) Cleavage of structural proteins during the assembly of the head of the becterlophage T4. Nature 227: 680-685.

Lederberg, EM., and Cohen, S.N. (1974) Transtormation of Salmonella typhimurium by plasmid deoxyribonucleic acid. J Bacteriol 119: 1072-1074.

Lndberg. F.P., Lund, B., and Normark, S. (1884) Genes of pyelonephritogenic $E$. coll required for digalactoside-specilic agglutination of human celle. EMBO J3: 1167-1173.

Lindberg. F., Lund, B., Johanseon, L, Normark, S. (1987) Localization of the receptor-binding proteln adhesin at the tip of the bacterlal pllus. Nature 328: 84-87. 
Lund, B., Lnctberg, F., Marklund, B.I., and Normark, 8. (1987) The PapG proteln is the elpha-D-Galactopyranoeyl-(1-4)-bota-0Galectopyranose-binding adhesin of uropathogenic Escherichia coll. Proc Natl Acad Sal USA 84: 5898-5902.

Lund, B., Lindberg, F., and Normark, S. (1988a) Structure and antigenic properties of the tip-located P-pilus proteins of uropathogenle Escherichla coll. J Eacterial 170: 1887-1894.

Lund, B., Marklund, B.l., Strómberg, N., Undberg, F., Karleson, K., and Normark, S. (1988b) Uropathogenic Escherichia colf can express serologically identical plif of different receptor binding speclificiles. Mol Microbiol 2: 255-263.

Mantatls, T., Fittach, E.F.s and Sembrook, J. (1982) Molecular Cloning. A Laboratory Manual, Cold Spring Harbor Leboratory, New York: Cold Spring Harbor Laboratory Preas.

Maurer, L, and Omdorff, P.E. (1987) Identilication and characterization of genes determining receptor binding and pllus length of Escherichla coll type I pill. J Becteriol 169: 640-645.

Mover, T. (1887) Molecular besis of surface antigen varlation in Mulwswia. Thends Cenet 3: 310-324.

Minlon, F.C., Abraham, S.N., Beachy, E.H., and Goguen, J.D. (1986) the genetic determinant of adheslve function in type I fimbriee of Escherichla coll ls distinct from the gene encoding the fimbrial subunit. J Bacteriol 165: 1088-1036.

Mireinan, D. (ed).) (1986) Microbial Lectins and Aogluthins: Properties and Blological Acthity. Now York: Wiley Interscience Press.

Moch, T., Hoschütaky, H., Hacker, Jo, Kronke, K-D., and Jann, K. (1887) leolation and cheracterization of the elpha-sialy/-beta2,3-galactosyl-specilic adhesin from timbriated Escherichia colf. Proc Natt Acad Sei USA 84: 3462-3466.

Normark, S., Hulitgren, 8., Marklund, B.lo, Strómberg, N., and Tennent, J. (1988) Biogenesis of plil adheeins associated with urinery trect infectlous Escherichila coll. Antonle von Leauwenhoak S4: 405-409.
Orakov, It, and Orekov, F. (1883) Serology of Escherichila coll fimbriae. Prog Allorgy 33: 80-105.

Orekov, $L_{\text {m }}$ and Orakov, F. (1985) Escherichla coll in extraintestinal Inlections. J Hyo Cam 85: 551-675.

Ott, M., Hacker, J., Schmoll, T., Jarchau, T., Korhonen, T.K., and Goebel, W. (1986) Analysis of the genetic determinants coding for the the S-fimbrial adhesin (sfa) in different Escherichia coll strains causing meningitis or urinary tract infections. Infect Immun 54: 646-853.

Ott, M., Schmoll, T., Goebel, W., van Die, I, and Hacker, J. (1987) Comparlson of the genetic determinant coding for the S-lim. brial achesin (sfa) of Escherichil coll to other chromosomally encoded fimbrial determinants. Infoct immun 55: 1940-1943.

Ott, M., Hoschutzky, Hu, Jenn, K., van Dle, L., and Hacker, J. (1988) Gene clusters for the S fimbrial adhesin (sfa) and F1C fimbrtae (foc) of Escherichla colt comparative aspects of structure and function. J Bacteriol 170: $3983-3990$.

Parkkinen, Ju, Rogers, G.N., Korhonen, T., Dehr, W., and Finne, J. (1886) Identlification of the O-linked sialyoligoseccharldes of olycophorin as the erythrooyte receptors for S-fimbriated Escherichie coll, infect immun s4i 37-42.

Rlegman, N., van Dle, I., Leunissen, J., Hoekstra, W., and

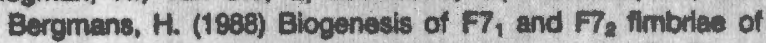
uropathogennic Escherichla coll. influence of the Fsof and FsoG protalns and localization of the Fso/FstE protein. Mol Microbiol 2: 73-80.

Savaga, D.C., and Fletcher, M. (eds). (1985) Bacterial Adhesion. New York: Plonum Press.

Schmoll, T, Hacker, J, and Cocbel, W. (1987) Nucleotide sequence of the sfaA gene coding for the 8 fimbrial protein subunit of Escherichia coll. FEMS Microblol Lett 41: 222-235.

Virkola, R., Westertund, B., Holtholer, H., Parkkinen, J., Kekomilli, M., and Kohonen, T. (1886) Einding characteristics of Escherichla coll adhesins in human urinary bladder. Infoct Immun 50: 2615-2622. 
This document is a scanned copy of a printed document. No warranty is given about the accuracy of the copy. Users should refer to the original published version of the material. 